\title{
ON A NEW AND PECULIAR FRESHWATER ISOPOD FROM MOUNT KOSCIUSKO.
}

\author{
By Chas. Chilton, M.A., B.Sc.
}

[With Plates XXIII. - XXVI.]

Towards the end of 1889 I received from the Trustees of the Australian Museum, Sydney, a small collection of Australian Crustacea, containing among others, some terrestrial and freshwater species collected by Mr. R. Helms while on an expedition to Mount Kosciusko on behalf of the Museum.* Among these I at once saw that one was quite different from any of the terrestrial and fresh-water crustacea previously described from Australia, and that it belonged to a genus Phreatoicus established by myself in 1882, for a peculiar blind subterranean Isopod found in wells in Canterbury, New Zealand. This genus was of special interest both because of the situation in which the original species was found, and because it combined characters belonging to several different families, and was also, to some extent, intermediate between the Isopoda and the Amphipoda. The discovery of a species belonging to the same genus in such a widely remote situation as Mount Kosciusko, and living under such different conditions is therefore of peculiar interest, and will probably have an important bearing on the difficult question of the origin of the blind subterranean forms. In the present paper, however, I do not propose to enter upon this question, as I hope to be able to do that on a future occasion when describing more fully the subterranean forms from New Zealand. For the present I shall content myself with describing the new species as fully as possible and with discussing the position of the genus among the Isopoda. It will be well, however, first to give the circumstances under which the species was taken, as they are given by the finder, Mr. R. Helms, a collector of whose zeal and accuracy I had had experience before he left New Zealand.

The specimens were, he says, taken at a place 'locally known "as "Piper's Creek," at an elevation of 5,700 feet or perhaps "rather more, on the track from "Pretty Point" towards the " "Ram's Head." The creek (or a least a branch of it) runs here 'through a, in damp weather, boggy flat, and at the time (early ' in March 1889) was slowly trickling along forming puddles here ' and there. In one of these puddles where there was only a little

* A short account of this expedition is given by Mr. Helms in the " Records of the Australian Museum," Vol. I., No. 1, p. 11. 
'water covering the black bog mud, perhaps from two to three 'inches, I made the find. In turning the stones (flat pieces such ' as frost will split from rocks-not boulders) I found no difficulty ' in picking the animals off, the most of them keeping quiet. They ' were pretty numerous under the stones, when at all, and looked ' exceedingly like the surrounding earth. Through this and their 'quiet habit I did not notice at first that they were so numerous, 'but seeing that they were interesting things (I had not seen any ' thing like it before) I took pretty well all I could lay hands on ; ' and this is the only time and place I have collected them although 'I have many a time turned stones in the neighbourhood and in 'similar localities.'

In speaking further of the locality he explains that it is nearly at the top of a branch of the leading plateau that extends, with various interruptions, towards the Ram's Head, Mount Townsend and Mount Kosciusko, the highest points of the range, and that it is only about one-half or three-quarters of a mile from the rise which forms the watershed between the river basins on the north and south. This rise is only about 30 or 40 feet higher than the place at which the animals were found. Consequently the amount of water in the creek can never be very great and, moreover, it is specially to be noted that for about six months of the year the place is covered with snow and the ground itself is probably frozen. On March 13th at "Pretty Point," Mr. Helms found the remains of his tea completely frozen in his "billy."

The Isopod about to be described is quite different from any of the fresh-water and terrestrial crustacea hitherto recorded from Australia, its nearest allies being marine in their habitat, and its occurrence on the top of a hill nearly 6,000 feet high is very peculiar. In connection with this it will be interesting to mention the following facts of a somewhat similar kind.

Mr. G. M. Thomson has taken in New Zealand a species, Pherusa carulea, Stebbing, at a height of about 3,000 feet. He gives the following account of its habitat:- "Hab. Several specimens of this species were taken in a runnel of water on the Obelisk (or OldMan) range, in the interior of Otago, at a height of about 3,000 feet. The stream was a little thing that one could have damned with the hand, and running at such a slope that I can hardly imagine how the crustacea are not washed away by every shower of rain. The Old-Man range is about 80 miles from the sea. The only other fresh-water Amphipod found in New Zealand (excluding the subterranean forms found by Chilton) is Calliope fluviatilis, mihi, which is very common."*

Here we have a species belonging to a genus chiefly marine in its habitat, found in a small stream on the top of a hill - a place which must frequently be covered with snow during the winter.

* See Transactions Zoological Society, London, Vol. XII., part vi., (1887) p. 208. 
In Lake Titicaca, South America, about 13,000 feet above sealevel, there are found several species belonging to the genus Allorchestes, a littoral genus which had previously yielded but one or two authentic fresh-water species.*

I have recently taken Idotea lacustris, Thomson, in Mihiwaka Creek (near Port Chalmers, N.Z.), a rocky mountain stream running from Mount Mihiwaka (about 2,060 feet) to the sea ; the place where I took the specimens was, however, perhaps not more than 200 or 300 feet above the sea. Before this the species was known only from Tomahawk Lagoon, a fresh-water lagoon quite close to the sea. Almost all the other species of Idotea are marine. It is quite possible that diligent search in our mountain lakes and streams would reveal other species that have been similarly preserved in these situations.

From the discussion given below of the position of this new species among other Isopoda, it will be seen that it does not fit into any of the usually recognised families of the Isopoda, and that it will therefore be necessary to form a special family for its reception. This family, which appears to approach more nearly to the Asellide than to any other, may be provisionally defined as follows :

\section{Family PHREATOICID E.}

Body sub-cylindrical, more or less laterally compressed. Mandibles with a well developed appendage. Legs distinctly divided into an anterior series of four, and a posterior series of three. Pleopoda broad and foliaceous and branchial in function, but not protected by an operculum. Abdomen large, of six distinct segments. Uropoda styliform.

\section{Genus Phreatoicus, Chilton.}

[Transactions New Zealand Institute, XV., p. 89.]

The following is the original diagnosis that I gave for this genus when I had only the one species $P$. typicus before me. It will include our present species without further modification.

Generic diagnosis.- "Body long, sub-cylindrical, laterally compressed. Upper antenna short, lower long, with flagellum. Mandible with an appendage First pair of legs subchelate, others simple; first four pairs articulated to body at the anterior ends of their segments and directed forwards, last three articulated at posterior ends of their segments and directed backwards. Abdomen long, of six distinct segments, last joined to telson. Sixth pair of pleopoda biramous, styliform. Telson large, subconical."

* Bulletin of the Museum Comparative Zoology, Cambridge, Vol. III. No. 16 , p. 361 . 
Our Mount Kosciusko specimen may be defined thus-

Phreatoicus australis, $s p$. nov., Plates xxiii. - xxvi.

Body with surface generally uneven, wrinkled, and with irregular depressions; head and anterior portion of pleon smoother, a few rather short setæ scattered over the surface and forming a short thick fur on the dorsal portion of the last segments of the pleon. Eyes small, round. Upper antennæ reaching to the end of the peduncle of the lower, peduncle apparently of three joints, the second much shorter and narrower than the first, third about as long as the second but narrower, not distinguishable from the flagellum which is composed of four joints with a minute terminal one and is somewhat swollen towards the end. Lower antennæ rather more than one-third the length of the body, peduncle of five joints, first four short, subequal, fifth half as long again as the fourth, flagellum longer than the peduncle. First pair of legs having the propodos large and swollen and forming with the dactylos a powerful subchelate hand. First five segments of pleon with pleura produced inferiorly, rounded below, inferior and posterior margins fringed with long setæ. Uropoda with peduncle reaching about as far as the end of pleon, rami about as long as peduncle, outer ramus shorter than the inner.

Length, about half an inch $(12.5 \mathrm{~mm}$.), breadth, about one-tenth inch $(2.5 \mathrm{~mm}$.) Colour, (in spirit) legs and part of the body light brown, the greater part of the body almost completely covered with marbled markings of a darker brown.

Hab. Mount Kosciusko Plateau-at Piper's Creek, about 5,700 feet above sea-level.

This species does not differ so much as might naturally have been expected from the original species of the genus, Phreatoicus typicu, a blind species found in wells in Canterbury, New Zealand. It is distinguished from that species however by the possession of eyes, by the colour, the much shorter lower antennæ and by a few other points in the surface of the body, the setæ, \&c.

I have given this brief diagnosis because I quite agree with the remark that Brooks makes in his "Report on the "Challenger" Stomatopoda" to the effect that it is desirable that a brief diagnosis of every new species should be given, although this should be supplemented wherever possible by a much fuller description giving the points in which it resembles other species as well as those in which it differs from them. I therefore proceed now to a detailed description of the various parts of the animal.

Body, (Plate xxiii., fig. 1.) - The length of the body is usually about half an inch, $(12.5 \mathrm{~mm}$.). It appears from the specimens that I have examined, that the female is slightly smaller than the 
male. The body is broadest at the third segment of the pereion and thence the breadth gradually decreases posteriorly, the pleon being somewhat laterally compressed. The depth of the body in the pereion is about equal to the breadth, but in the pleon, owing to the pleura being produced downwards, the depth is about twice the breadth. 'The dorsal surface is regularly rounded and very convex, the ventral surface of the pereion is almost flat so that the pereion is pretty regularly sub-cylindrical ; the pleon presents the appearance of a semi-cylinder laterally flattened.

Head, (Plate xxiii., fig. 1.)-The dorsal surface of the head is very convex and curves downwards anteriorly making the outline as seen in a lateral view subtriangular. The anterior margin is deeply emarginate in the centre behind the bases of the superior antennæ. A clearly marked depression runs across the dorsal surface near the posterior margin and extends down the sides, running out into the posterior margin of the head. This mark reminds one of the similar depressed mark found on the head in many species of Idotea. The inferior margin is nearly straight, the notch serving for the articulation of the base of the mandible being small and shallow, and by no means so distinct as in Asellus aquaticus as described and figured by Sars.* In front of the eye and a little below it is a deep cleft in the anterior margin of the head, and a slight depression extends backwards from this cleft below the eye.

Eyes.-The eyes are situated laterally on the portion of the head which is slightly produced on each side at the bases of the antennæ. They are of moderate size, round in shape and consist of about 20 lenses arranged fairly regularly in circular rows and separated from one another by distances about equal to the diameter of the lenses.

Pereion, (Plate xxiii., fig. 1.) - The first segment of the pereion is closely attached to the head and appears to be capable of little or no independent motion, though the division mark between the two is very distinct. It is worth while to recall the fact that this is also the case with some species of Idotea, in some of which as Idotea elongata, Miers, the union of the head with the first segment of the pereion has gone so far that the line of division is almost obliterated. The head and first segment of the pereion are confluent also in Apseudes and in Tanais. When viewed from above the first segment is seen to be very short (narrow) in the centre, and to have the anterior and posterior margins both concave for the reception of the head and second segment of the pereion respectively. In side view the segment widens inferiorly and is somewhat produced anteriorly so as to impinge closely upon the head.

\footnotetext{
* Crustacés d’eau douce de Norvège, p. 94, pl. viii., fig. 9.
} 
The second, third, and fourth segments of the pereion are all about equal in length, being about three times as long as the first in the centre. They are of the same length throughout from side to side. The inferior margins are slightly concave in the centre for the reception of the basi of the legs (epimera) and have the anterior angleslightly produced and tipped with setæ while the posterior angle is regularly rounded. (See Plate xxiii., fig. 1, and also Plate xxv., fig. 4).

The fifth, sixth and seventh segments are similar to one another, the fifth being somewhat shorter than the fourth, and the sixth and seventh each shorter than the preceding segment. The epimera extend along almost the whole of the inferior margins and fit into rather deep triangular emarginations; both the anterior and posterior angles of the margins are tipped with setæe (see Plate xxv., fig. 5).

Epimera.-The first to fourth epimera inclusive are all similar in form, and consist of two lobes separated by a distinct cleft reaching upwards from the inferior margin more than half way to the upper margin. The epimeron of the first segment is rather deeper than those of the other three, in the first and second the two lobes of the epimera are of about equal size, in the third and fourth the anterior lobe is larger than the posterior. The margins of the epimera are free from setæ. (Plate xxv., fig. 4.)

The epimera of the fifth, sixth, and seventh segments are all similar and are triangular in shape fitting into a triangular emargination in the inferior margins of the segments. The pusterior angle is produced a little and is tipped with three or four setæ, while the anterior angle is somewhat rounded and bears no setæ. There are usually two or three short setæ on the surface of the epimera. (Plate xxv., fig. 5.)

Pleon.-The first segment of the pleon is nearly as long as the seventh segment of the pereion in the centre of the dorsal surface, but gradually narrows somewhat inferiorly. It extends downwards slightly beyond the epimeron of the seventh segment of pereion and has the lower margin regularly rounded. The second, third, fourth, and fifth segments are similar, slightly longer dorsally and not narrowing inferiorly and they are produced downwards considerably further than the first segment. The sides of the segments (pleura) are thus fully as well developed as in any of the Amphipoda, and form, as in the Amphipoda, a lateral protection for the pleopoda. The body part proper in the fifth segment is separated from the pleuron by a slight depression. The sixth segment and the telson appear completely coalesced, forming a tail piece regularly convex above, curving posteriorly as well as from side to side; posteriorly it ends in a small narrow projection tipped with stiff setæ. From the upper corner of the articulation of the uropoda with the segment a short ridge bordered with setæ ex- 
tends anteriorly and upwards about half way to the anterior margin of the segment. The inferior and posterior margins of the first to fifth segments of pleon (inclusive) are regularly fringed with long setæ, thickly set on the inferior margin but more sparsely placed on the posterior margin. On the inferior margin of the sixth segment the corresponding setæ (about 15 or 16 in number) are short and stout, almost spiniform, most of them bear 4 or 5 pectinations on the posterior edge toward the end of the setæ. The projections at the end of the tail piece are thickly covered with setæ of various sizes, some of them thick and spiniform.

Surface of body. - In the pereion the surface has a crinkled appearance caused by numerous shallow depressions separated by small narrow ridges; the first segment is smoother than the others and the surface of the head is also smooth. The surface of the pleon with the exception, to some extent, of the dorsal surface is smooth. In the pereion there are a few setæ partially arranged in tufts scattered about on the dorsal surface, and the inferior angles both of the segments and of the epimera usually bear a few short setæ. In the pleon, especially in the posterior segments, the dorsal surface is covered with a thick fur of short setæ with some longer scattered setæ as in the pereion, but more numerous. The long setæe on the margins of the segments of the pleon have been already mentioned.

The ground tint of the colour is a light brown and is seen in the appendages, but in the body this ground tint is almost covered with marbled markings of a much darker brown, the lighter colour showing up in more or less rounded patches on the head and here and there on the segments of the pereion. The lateral portions of the pleon are usually darker than the other parts of the body and of a uniform slaty colour. This colour is probably protectiveMr. Helms notes that the animals looked exceedingly like the surrounding earth.

Upper antenna. (Plate xxiii., fig. 2.)-The upper antenna is short, scarcely reaching to the end of the peduncle of the lower antenna, the peduncle apparently consists of three joints, but is not clearly distinguishable from the flagellum. The first joint is partially hidden by the head, it is longer and broader than the second joint, which is of about the same length as the third, but broader. The flagellum consists of from 5 to 7 joints, the proximal joints usually short, the others longer and swollen, this being most noticeable in the third and fourth joints from the end; the terminal joint is very small and is tipped with a few setæ. The swelling of the terminal joints is chiefly confined to the chitinous integument, the central portion containing the muscles \&c. not being similarly swollen. The setæ on the antenna are few and small; there are a few on the second and third joints of the peduncle and on some of the joints of the flagellum. On the last four joints 
of the flagellum are "auditory cilia," one or two on each joint. These are very small but are of the usual shape being similar to those of Asellus aquaticus as figured by Sars.*

Lower antemna. (Plate xxiii., fig. 3.)-The peduncle consists of five joints and is considerably shorter than the flagellum. The first joint is short, the second, third, and fourth, are subequal in length, the fifth about half as long again as the fourth, but narrower; the third is rounded above and bears two small tufts of setæ, small tufts are also present on the fourth and fifth joints. The first joint of the flagellum is longer than the succeeding, the next three or four are usually short, the others subequal in length but gradually becoming narrower; towards the end they also increase a little in length. Each joint bears one or two small setæ above and below at the distal end.

The upper lip (Plate xxiii., fig. 4) is large and strong, regularly rounded distally, the centre being slightly produced. It bears a number of short setæ thickly set together and converging towards the centre of the distal margin.

The mandibles (Plate xxiii., figs. 5 and $5 a$ ) are large and powerful. In a side view of the head the basal joint can be easily seen extending along the anterior portion of the lower margin of the head; just below the base of the lower antenna it gives off the threejointed palp which extends anteriorly beneath the antennæ, from this point the basal portion of the mandibles extends downwards and forwards and curves inwards to form the cutting edge. From the inner surface arises the large and powerful molar tubercle which extends obliquely upwards and inwards almost at right angles to the portion of the mandible from which it springs, until it reaches the median line and meets the molar tubercle of the other side. The two mandibles are of the same size and general appearance but differ in a few details. It will be convenient to describe the left mandible first.

The cutting edge of the left mandible consists of two separate processes one inside the other; the outer one consists of four sharp strong teeth, brown in colour, and the inner one of three similar teeth. Figure $5 a$ of plate xxiii., shows the ends of these two processes as seen from the inside. Within these two processes is another, the chitinous integument of which is less strong and thickened; it is rather slender but expands somewhat distally and extends inwards to the median line so that the end of it is in a line with the cutting edge of the mandible and the end of the molar tubercle; the end is crowned with about 15 to 20 sharp strong setæ which project radially from the end. Between the base of this process and that of the molar tubercle are four or five plumose or pectinated setæ nearly as long as the last mentioned

* Crustacés d'eau douce de Norvège, plate viii., fig. 19. 
process. The molar tubercle is nearly circular in section and owing to the curving of the basal portion of the mandible is of considerable length, the extremity is square-truncate and is thickly covered with short setæ arranged in numerous rows running more or less parallel to one another across the end. Owing to the cutting edge of the mandibles projecting in one direction and the molar tubercle in another it is difficult to make a good drawing of them, to show all the parts and give a good idea of the arrangement of them. Figure 5 of plate xxiii., shows the left mandible as seen from above and a little from within so as to bring the teeth of the eutting edge into view. This part of the mandible projects downwards through the plane of the paper, while the molar tubercle extends obliquely upwards and is somewhat foreshortened in the drawing.

The right mandible differs from the description already given in having no second or accessory cutting edge-in this respect resembling Asellus aquaticus. The next process crowned with strong setæ is present but appears to have the end narrower so that the setæ are closer together and form two rows, one projecting on each side; the molar tubercle has the extremity oblique instead of square-truncate as in the left mandible.

The mandibular palp is the same in both mandibles. It consists of three joints, the first is short being not much longer than broad, on the outer edge towards the end it bears a number of setæ and on the basal part of the mandible just posterior to the articulation of the palp is a small group of three setæ. The second joint of the palp is about twice as long as broad, towards the distal end it bears several rather long setæ in groups, some being on the outer margin and others on the under surface. The third joint is about two-thirds as long as the second, it is a little narrowed at the base and narrows also distally. The upper margin is rounded and free from setæ, the under surface bears a double row of setæ which gradually increase in length towards the distal end, the last two or three being considerably longer than the others and about as long as the joint itself. The setæ in one row bear projecting teeth on one side, those in the other appear simple.

From the description here given it will be seen that the mandibles are not very different in form from those of Asellus aquaticus as described by Sars, the chief difference being that the setæ between the cutting edge of the base of the molar tubercle are placed on a raised base so as to form a distinct process, and are moreover somewhat different in character from those found in Asellus.

The lower lip (Plate xxiii., fig. 6) consists of two rounded lobes somewhat widely separated distally and connected at the base by a flexible membrane fringed at the margin, and generally seen folded upon itself or puckered when the lip is removed for exam- 
ination. Each lobe is somewhat oblong in shape with the distal angles rounded off and densely fringed with setæ, all more or less directed inwards towards the median line.

The first maxilla (Plate xxiii., fig. 7) consists of two parts, the outer part is longer and broader than the inner, its total length is nearly four times the greatest breadth, the outer edge is curved so that the distal half is directed somewhat inwards to the median line. On the end it bears about 10 to 12 short stout spiniform setæ arranged mainly in two rows, the outer setæ are the largest, the others decreasing in size inwards, some of the smaller are minutely denticulated on the inner side near the middle. Both the inner and outer margins of the outer portion of the maxilla bear a number of very fine hairs, and near the inner distal angle one or two delicately plumose setæ arise a little below the base of the spiniform teeth.

The inner portion of the maxilla is only about half as long as the outer, and it is also narrower. It curves somewhat inwards and bears fine hairs on both margins. The extremity bears four or five large setæ somewhat distant from one another, each being densely but finely plumose in the distal half. In addition to these there are also two simple setæ at the base of the plumose setæ, one at the outer distal angle, and the other at the centre of the surface of the joint.

In describing the first maxilla of Ianthe speciosa, Bovallius speaks of the two portions similar to those just described, as the exopodite and endopodite respectively. ${ }^{*}$ The appendage is undoubtediy difficult of interpretation, but from Boas's comparative researches it appears more probable that these two portions represent the internal and external lacinice arising from the basos and ischios respectively, the remainder of the typical limb being lost. $\dagger$

The second maxilla (Plate xxiv., fig. 1) consists of a basal portion prolonged at its inner distal angle into a long rounded lobe, and two lobes external to this articulating with the basal portion. The inner margin of the base is very slightly concave, and is supplied throughout its whole length with a thick fringe of long setæ, these setæ are arranged in a distinct line which at the end leaves the margin and is continued for a short distance along the surface of the inner fixed lobe. The rounded end of the lobe is also fringed with setæ, the innermost of which are pectinated, while those in the row along the inner margin are simple.

The two articulated lobes are of about the same size, sub-oblong in outline, curving slightly inwards and with the ends obliquely

* "Ianthe, a new genus of Isopoda," Bihang. Till. K. Svenska Vet. Akad. Handlingar. Band 6, No. 4, p. 7.

† See Parker--"'The skeleton of the New Zealand Crayfishes." (Studies in Biology for New Zealand Students, No.4) p. 21 ; also Boas-"Studien üb die Verwandtschaftsbeziehungen der Malakostraken." 
truncate-sloping inwards. The end of each is supplied with from 12 to 16 long setæ, nearly as long as the lobes themselves. These setæe curve inwards and have the inner margins supplied with short pectinations which project at right angles to the setæ. In the outer setæ on each lobe the pectinations are fine and minute, but in the inner setæ they are much stouter and rounded at the end. There is a tuft of fine setæ on the outer side of the basal portion, at the point where the outer lobe articulates with it. The outer lobe is slightly concave and overlaps and partially encloses the middle lobe, which in its turn overlaps the lobe formed by the prolongation of the basal portion. This appendage, like the first maxilla is difficult of interpretation, but it appears probably, according to the authorities already quoted, that the innermost lobe represents the internal lacinia arising from the coxos, and the two articulated lobes the internal lacinice arising from the basos.

The maxillipedes (Plate xxiv., figs. 2, 3, and 4) are large and well developed and cover the greater part of the under surface of the mouth parts. The basal joint (coxos) is well developed and is distinctly marked off from the succeeding joint the basos. It is broader than long, and from its outer distal margin arises a large flat plate representing the epipodite. This fits closely on the under surface of the head on each side covering and protecting the other mouth parts ; it extends as far forwards as the mandibles. In outline it is broadly elliptical, about half as long again as broad; the outer edge bears about eight short setæ sparsely arranged. The basos is more than twice as long as broad, rectangular, inner margin quite straight, outer margin curving slightly outwards towards the distal end. From the inner margin a flat plate projects inwards at right angles to the surface of the maxillipede and this is produced distally a little beyond the end of the inner side of the ischios. Only the distal end of this plate can be seen when the maxillipede is viewed from below (i.e. from without) but the whole can be readily seen if it is viewed from above (i.e. from within), and the plate is bent back upon the rest of the maxillipede. This view is shown in Plate xxiv., fig. 3. If the plate were left in its natural position when the maxillipede is viewed directly from above, only the inner edge of the plate would be seen. The end of this plate is truncate and thickly fringed with stout setæ, some of them plumose, the inner surface is also thickly covered with setæ, some of them simple, but the others along the margin long and densely plumose. Besides these setæ there are on the outer edge of its distal portion three strong curved setie hooked at the end. These appear to hook into the corresponding setæ on the other side, and to keep the two maxillipedes closely together.

From the outer distal angle of the basos (on its outer surface) arise four very long setæ directed inwards and reaching nearly to the end of the plate already described. The ischios is very short, 
transverse, and bears four or five setæ at the outer distal angle and two others at the inner distal angle. The meros is subtriangular, having the outer angle produced nearly to the end of the carpus, while the inner edge is only as long as that of the ischios; the inner distal angle is rounded and bears about 6 or 7 setæ, the outer distal portion of the joint is somewhat concave for the reception of the carpus, and has the margin fringed with long setæ. The carpus is somewhat sunk in the meros, it is narrowed at the base but widens distally and has the end truncate; the inner margin is densely fringed with two or three irregular rows of setæ and there is a small tuft at the outer distal angle. The propodos is elliptical, widest towards the distal end; the inner margin, like that of the carpus, is fringed with setæ, the outer margin bears six long setæ towards the distal end. The dactylos is broad and elliptical and arises from a slight concavity at the end of the propodos; the whole of the inner margin and the distal half of the outer margin are fringed with long setæ, those at the apex being the longest and also the stoutest.

From the description given above it will be seen that the maxillipedes of Phreatoicus bear a close general resemblance to those of Asellus aquaticus.

The first thoracic leg (or first gnathopod). (Plate xxiv., figs. 5 and 5 a.) - This appendage has the dactylos bent back upon the enlarged propodos so as to form a powerful subchelate hand similar to that found in many Amphipoda. This form of limb is not so common among the Isopoda, but is found in several genera such as Anthura, Asellus \&c. The basos is strong, about two and a half times as long as the greatest breadth, somewhat constricted near the base; on the anterior margin is a row of 5 or 6 long simple setæ, and there is a tuft of similar setæ at the postero-distal angle. The ischios is rather more than half as long as the basos, and is subrectangular, slightly narrowed proximally; there is a tuft of long simple setæ about the middle of the anterior margin and two smaller tufts on the posterior margin. The meros is subtriangular and is produced anteriorly and distally into a rounded lobe partially surrounding the carpus and fringed all round with long simple setæ, it also bears a tuft on the posterior margin. The carpus is also subtriangular and has the posterior margin supplied with a fringe of long setæ, sometimes indistinctly separated into two tufts, the jurction of the carpus with the propodos is oblique. The propodos is very large and ovate, the anterior margin strongly convex with a small tuft of setæ at the base of the dactylos and another placed more proximally; the palm is oblique, somewhat convex and occupies about two-thirds of the posterior margin but is not clearly defined; it is armed with a row of stout and very acute spiniform setæ, and also bears a row of long simple setæ, three or four tufts of setæ are situated on the surface of the propodos near the palm. The dactylos is stout and fits closely on to 
the palm, there is a row of about 7 or 8 fine setæ along the inner margin and a small tuft towards the end of the outer margin; the extremity is indistinctly separated from the rest of the dactylos and bears the terminal unguis and on the inner margin a small secondary tooth.

The description just given and the figures 5 and $5 a$ of Plate xxiv. apply to the first thoracic leg of a fully grown male. In the female and probably also in young male the limb is of the same general shape, but the subchelate hand is less strongly developed, the propodos being much less swollen.

The second thoracic leg (second gnathopod) (See Plate xxv., fig. 1.) has the basos and ischios similar to those of the first leg but the fringe of setæ on the anterior margin of the basos is much longer and contains about fifteen setæ, and the tuft on the anterior margin of the ischios contains much stouter setæ: the meros is subtriangular, narro:v at the base but does not overlap the carpus, the posterior edge bears about 6 or 7 stout setæ and a number of others more slender, and there are similar tufts at the middle of the anterior margin and at the antero-distal angle. The carpus is not so short and triangular as in the first leg, the anterior margin is rather convex and bears a tuft of fine setæ at the anterodistal angle, the posterior margin is straight and bears six stout setæ increasing in length distally. The propodos is subrectangular rather more than twice as long as broad, and is somewhat longer than the carpus; the anterior margin is slightly curved and bears a few setæ chiefly at the base of the dactylos, the posterior margin is straight and bears 5 or 6 stout spiniform setæ and a few slender ones. The dactylos is more than half as long as the propodos and is similar to that of the first pair of legs except that it is smaller and bears fewer sete upon it. Fig. 1 of Plate $x x v$. represents the third thoracic leg, but will do equally well for the second.

The third thoracic leg (first pereiopod) (Plate xxv., fig. 1) is similar in all respects to the second, and is of about the same size.

The fourth thoracic leg (second pereiopod) (Plate xxv., fig. 2) of the male is rather shorter than the two preceding legs and differs from them in a few small details. The basos and ischios are quite similar to those of the second and third legs, and are nearly as large ; the meros and carpus are similar but are shorter and stouter in proportion; the propodos is also stouter and has the anterior margin strongly convex, the posterior margin is very short and bears two very stout spiniform setæ placed side by side and defining a slightly concave palm; the dactylos is strongly curved and bends back upon these two setæ so as to form a powerful claw. It is only in the male that the fourth leg is thus modified, in the female it does not differ appreciably from the two preceding legs. 
The four pairs of legs now described form an anterior series, differing considerably in form from the remaining three which are similar to one another and form a posterior series, the members of which increase in size posteriorly.

The fifth thoracic leg (third pereiopod) (See Plate xxv., fig. 3) is slightly longer than the fourth. The basos is produced posteriorly into a thin flat expansion with convex margin fringed with long setr-much in the same way as in many Amphipoda. The isclios is large, about two thirds as long as the basos and is subrectangular, though expanding somewhat distally; it bears tufts of stout setre on both margins. The meros, carpus, and propodos are all similar and subrectangular, but each is longer and narrower than the preceding, they all bear numerous tufts of stout spiniform setæ on both margins. The meros has the postero-distal angle slightly produced as in many Amphipoda.

The sixth and seventh thoracic legs (fourth and fifth pereiopoda) are similar to the fifth but are much larger, the various joints are all similar to the corresponding joints of the fifth leg, but they bear a greater number of setce, and the setæ themselves are stouter, the basos has the posterior margin more produced and more convex and the dactylos is longer and more slender.

Figure 3 of Plate xxv., shows the last (seventh) leg, but will do almost equally well to represent the general appearance of the fifth and sixth.

It is worthy of note that although these thoracic legs are very Amphipodan-Jike in general appearance, they all have the ischios large and well developed instead of being small and very short as in almost all the Amphipoda, and that although the first pair of legs has a well developed subchelate hand, the second pair is quite simple, while as a general rule both pairs are more or less subchelate in the Amphipoda. The resemblance of these legs to those of the Amphipoda is therefore more superficial than real, and a comparison of my figures with those given by Sars of Asellus aquaticus will show that there is a close general resemblance between the two.

I have called all these legs "thoracic legs" instead of speaking of the first two pairs as "gnathopoda" and the remainder as "pereiopoda" as is usually done in the Amphipoda. This would have made an arbitrary and misleading distinction between the second and third pairs which are precisely similar to each other, while it would probably have led to confusion if I had spoken of them all as "pereiopoda," as those of the last pair would then be the seventh pereiopoda, while if the plan adopted with the Amphipoda were adhered to they would be the fifth pereiopoda. It seems to me a pity however that the term "pereiopoda" has not been applied to all the appendages of the pereion both in the Amphipoda and Isopoda, leaving the term "gnathopoda" a special 
one to be used where necessary instead of "first" or "second pereiopoda."

The first pair of pleopoda (Plate xxvi., fig. 1) like the following pairs appears to be branchial in function and is not specialized to form an operculum as in Anthura, Janira, \&c. The basal portion, probably representing the coxos and basos, is subrectangular and has the outer edge fringed with long setæ, while the inner edge bears a few long setæ chiefly towards the distal end. The endopodite is shorter than the exopodite, irregularly elliptical in form, margins quite free from setæ and with a shallow emargination at the extremity. The exoporlite has the inner margin nearly straight and the outer one slightly curved and converging distally towards the inner so that the joint is widest towards the base and narrows towards the extremity. The whole margin of the exopodite is bordered with setæ, those near the end longest and plumose, the others simple.

The second pleopoda (Plate xxvi., fig. 2). In the male these appendages differ from those of the female in having a part of the endopodite specially modified to form a "penial filament." The whole appendage is considerably larger than the first pleopod. The basal portion is subrectangular and is almost completely filled with the powerful muscles which move the endopodite and exopodite. The endopodite is somewhat swollen near the base and gives off on the inner side a long narrow semi-cylindrical process (the "penial filament") which is articulated to the other portion of the endopodite, and is moved by powerful muscles situated in the swollen portion of the base. This process extends beyond the end of the endopodite as far as the extremity of the first joint of the exopodite; it curves slightly outwards and appears to be hollowed out along the outer side so as to form a half tube; at the end it hears a few short stout setæ. Most probably this process acts as an accessory copulatory organ. A somewhat similar organ has been described and figured by Bovallius in Ianthe speciosa. * Beddard has described organs named by him "penial filaments" in Ichnosoma bacilloides and in Acanthomunna proteus, which appear to be similar in function to the one found in Phreatoicus australis $\dagger$ In Asellus aquaticus, as described by Sars, the whole of the second pleopod seems to be modified in a very different way for reproductive purposes. $+\frac{\ddagger}{+}$ In some genera, sach as Ianthe, Jera, and apparently also in Ichnosoma and Acanthomunna the first pair of pleopoda (as well as the second) is modified to form a male organ, but this is not the case with Phreatoicus.

* Bihang. Till. K. Svenska Vet. Akad. Handlingar Band 6, No. 4, p. 10, plate iii., figs. 30 and 31 .

† Report of the "Challenger" Isopoda, Part II., p. 46, plate vi., fig. 10. and p. 49, plate xii., fig. 13.

‡ Crustacés d'eau douce de Norvège, p. 101, pl. x., figs. 6 and 7. 
The remaining portion of the second pleopod is branchial in function. The rest of the endopodite is similar to that of the first pleopod, margins free from setæ and with an emargination at the distal end. The exopodite consists of two joints, the first one subelliptical with a rounded lobe extending back along the outer margin of the base and partially covering it, both margins are fringed with setæ, those near the proximal end simple, but those at the distal end very long and densely plumose ; the second joint is small, elliptical, and has the margin fringed with twelve very long plumose setæ.

The second pleopoda in the female differ from those of the male only in the absence of the "penial filament," as the result of which the base of the endopodite is not swollen and does not contain the powerful muscles found in the male.

The third pleopoda (Plate xxvi., fig. 3) are similar to the second pleopoda (of the female) except that the exopodite has the first joint more narrowed distally. Arising from the outer margin of the basal portion (the protopodite) is an ovate appendage which perhaps represents the epipodite. The margins are fringed with long simple setæ and the integument appears thin and delicate so that this portion probably is branchial like the rest of the pleopod. I have not found this appendage in the first and second pairs of pleopoda.

The fourth and fifth pleopoda (Plate xxvi., fig. 4) are similar in all respects to the third, but the endopodite gradually increases in size as compared with the exopodite, till in the fifth pleopod it reaches to the end or somewhat beyond the end of the first joint of the exopodite.*

* Attached to the pleopoda and apparently partially imbedded in the integument, I have frequently found a number of oval or egg-shaped bodies, the real nature of which I have not been able to ascertain. They may perhaps be algæ of some kind. Beddard found a "number of green bodies of varying form" in the interior of the thoracic appendages of Astrurus crucicauda, which he took to be parasitic algæ. He also refers to the fact that parasitic Infusorians (Anoplophyra circulans, Balbrani, Recueil Zool. Suisse, ii., 1885, p. 277) are known from the appendages of Asellus. [See 'Report of the "Challenger" Isopoda,' Part II., p. 38, footnote ] In one of the specimens of Phreatoicus australis I found in some of the thoracic legs a number of oval bodies, which I at first thought were the same as those found on the pleopoda, but they differ in some points and are perhaps different-possibly they are infusorians of some kind. They are not quite 1/50 inch in length, elliptical, about half as broad as long, surface smooth, and they have been deeply stained by the borax-carmine with which I stained the appendages before mounting them, the thick outer portion or integument has not been stained so deeply as the inside. The bodies found on the pleopoda appear to be on the surface and partially imbedded in the integument; they are of about the same size but have scarcely been stained by the borax-carmine and appear yellowish and have the surface much wrinkled; some of them are shown in position in Plate xxvi., fig. 4 at $a$, and an enlarged view of one 
So far as my knowledge goes, the division of the exopodite of all the pleopoda except the first, into two distinct joints is very unusual in the Isopoda; the plate attached to the outer margin of the base (epipodite?) also appears to be peculiar to this genus

The Uropoda (Plate xxv., fig. 6) are well developed and extend somewhat beyond the extremity of the pleon. The basal joint is as long as the longer of the two rami and is very stout; on the under side near the base it bears two groups of stout setæ, each group containing about six or seven. The upper surface is broad and slightly concave, each of the edges being supplied with a row of stout spiniform setæ, which are more numerous on the outer than on the inner edge, and are largest towards the distal end. At the end of the base below the articulation of the outer branch are two very thick setæ with a few pectinations at the end on the upper side only. Many of the other stout setæ on the uropoda are pectinated in the same way though not to the same extent.

The two rami are similar, subcylindrical in section, tapering distally and curving slightly upwards. The inner is slightly the longer, both bear stout setæ and a larger number of fine setæ or hairs arranged in groups chiefly on the upper surface; the ends of each are free from setæ.

Sexual differences.-Of the specimens I have examined, nearly two-thirds were undoubtedly males, all having the external male organs present at the base of the seventh pair of thoracic legs. One of these is shown in Plate xxvi., fig. 6. The remainder of the specimens were females. They are similar in general appearance to the males but are slightly smaller, the subchelate hand of the first pair of thoracic legs is less strongly developed, the fourth pair of thoracic legs does not present the special modification found in the male, and the second pair of pleopoda are of normal form. None of the specimens examined bore eggs or young, but some had what appeared to be small brood plates already developed on the bases of the legs of the second, third and fourth segments of the pereion.

\section{Position of Phreatoicus among the Isopoda.}

When I originally described the genus Phreatoicus in 1882 I

in fig. 5. Besides these bodies I have found on other pleopoda great numbers of other bodies which appear like empty spherical cases with a small oblong or elliptical opening-many of them being broken or imperfect. I have not the least idea what they may be, but they are so numerous on the pleopoda of some specimens that I thought it best to mention them. They appear merely to rest on the surface of the pleopoda but whether their presence there is accidental or not I cannot say. A small stalked Infusorian (Vorticella?) is also found in great abundance attached to the hairs of the pleopoda, three or four individuals usually branching from the one stalk. 
placed it under the Isopoda, and pointed out various separate resemblances to the Idoteide, the Anthurida, and the Tanaide, and also drew attention to the several superficial resemblances to the Amphipoda, but after doing this I left the exact position of the genus among the other Isopoda an open question for the time.* When preparing the "Critical List of the Crustacea Malacostraca of New Zealand," Mr. Thompson, judging from the general appearance (he had not had an opportunity of examining specimens), was inclined to place the genus under the Amphipoda, an opinion with which I did not agree, and accordingly it was arranged that it should be placed between the Amphipota and the Isopoda under a separate heading with the following note:--."The systematic "position of this singular Crustacean is doubtful. In general "appearance I was inclined to place it among the Amphipoda, but "from the fact of the first five pairs of pleopoda acting as branchial "organs, and from the absence of any such organs attached to "the pereion, Mr. Chilton places it among the Isopoda.-G. M. T."†

Unfortunately however the separate heading was omitted by some error, probably on the part of the printer, and the genus therefore appears under the last family of the Amphipoda, viz. the Platyscelide, as though it belonged to that family. It is no wonder therefore that the Rev. T. R. R. Stebbing in his notice of the "Critical List" says, in speaking of Phreatoicus-_" I do not know what are the special reasons for classing it among the Platyscelidæ." He also says__"The list [i.e. our "Critical List'] continues with-'Suborder II. Isopoda. Tribe I. Anisopoda. Fam. I. Tanaidr,' and probably the affinities of Plireatoicus will eventually prove to be rather with the Tanaidx than with the Hyperina." In another reference to the species Phreatoicus typicus $\mathrm{Mr}$. Stebbing calls it "a singular well-shrimp, of a new genus and species, which appears to be an Isopod with some remarkable Amphipodan affinities."

The fuller examination that I have now made in describing the new species Phreatoicus australis has convinced me that the genus has few affinities to the Amphipoda, though it presents several resemblances to them, and that these resemblances are more or less superficial. They are briefiy (1) The body, especially in the pleon, is somewhat laterally compressed. (2) The pleura of the segments of the pleon are produced downwards so as to protect the pleopoda on either side. (3) The legs of the pereion consist of an anterior series of four, and a posterior series of three. The general appearance of the legs and also of the uropoda is not

* See Trans. New Zealand Institute, XV., p. 91.

+ Transactions New Zealand Institute, XVIII., p. 151.

+ Report on the "Challenger" Amphipoda, p. 587.

$\S$ Loc. cit., p. 543 . 
unlike that common among the Amphipoda. (5) The pleon is formed of six separate segments and is better developed than most Isopods.

I think these are all the points in which Phreatoicus specially resembles the Amphipoda and an examination of them shews that none is of any particular importance in its bearing on the systematic position of the genus. Most of the Isopoda are, it is true, more or less dorso-ventrally compressed, and I do not now recollect any one in which there is any lateral compression as in Phreatoicus, but here the lateral compression is not great and is chiefly confined to the pleon where the downward prolongation of the pleura is no doubt a special adaptation for the protection of the pleopoda and may very well have arisen quite independently of the similar adaptation in the Amphipoda. The pereion of Phreatoicus is almost sub-cylindrical and thus resembles Anthura, Paranthura, and some of the species of Idotea, where there is no dorso-ventral compression. On the other hand there are genera among the Amphipoda in which the body is more or less cylindrical and shows no lateral compression (e.g. Corophium, Haplocheira \&c.,) and in some such as Icilius and Iphigenia the body is very much flattened as in the Isopoda.

The division of the appendages of the pereion into an anterior and a posterior series has been used by Dana in separating the Anisopoda from the typical Isopoda and the possession of an anterior series of four, and a posterior series of three is by no means a special Amphipodan character. It is, moreover, probably of little importance from a systematic point of view, seeing that it is found in such widely different genera as Phreatoicus, Stenetrium, Munnopsis, Tanais, and Arcturus, and its adoption as the chief bond of connection between a number of forms results, as Mr. Haswell has pointed out, in "an extremely artificial arrangement." * In connection with the fourth point, the general Amphipodan appearance of the legs and the uropoda, I have already shown that this is more apparent than real, as the legs all have the ischios well developed and fairly long instead of very short as in most Amphipoda. The uropoda again present no greater resemblance to the Amphipoda than to several of the Isopoda such as Asellus.

In the possession of an abdomen formed of six distinct and well developed segments Phreatoicus certainly differs from the greater number of the Isopoda, but this character is also possessed by the Apseudida and the Tanaidce, which are usually classed among the Isopoda, and by Limnoria, and also to a greater or less extent by many of the Cymothoidce and Oniscidce \&c. On the other hand

* Revision of the Australian Isopoda, Proc. Linn. Soc., N.S.W., IX.. part iv., p. 10. 
although the segments of the pleon are generally separate and well developed in the Amphipoda, the latter never have all the first six pairs of pleopoda similar to one another and all branchial in character as in Phreatoicus, and this fact is of itself, in the absence of characters to the contrary, sufficient to show that Phreatoicus must be placed among the Isopoda and not under the Amphipoda.

Having now discussed the supposed Amphipodan aftinities of Phreatoicus, and having come to the conclusion that they are by no means sufficient to remove it from the Isopoda, we have next to consider its affinities to other Isopoda. When originally describing the genus I briefly compared it with the Tanaidae, the Anthuride, and the Idoteide, but did not at that time notice its affinities to the Asellide, although these are, as I hope to be able to show, greater than those with any of the other three groups.

The resemblance to the Tanaidce is not great, and is confined to the more or less cylindrical form of the body, the direction of the legs and the possession of an abdomen of six distinct and well developed segments. All of these characters are however separately shared by other groups, and the differences between the Tanaidce and Phreatoicus in other respects (which it is unnecessary to point out) are very great, so that we may safely conclude that there is no very close affinity between the two.

The resemblance to the Anthuridce is somewhat closer. In addition to the general resemblance in the form of the body there is a fairly close resemblance in the legs, and the abdomen of the Anthuridoe though by no means so well developed as in Phreatoicus is sometimes composed of more or less distinct segments bearing pleopoda not very dissimilar. The mouth parts of the Anthurida are however very different, though in some cases they are no doubt specially modified to form an apparatus probably suctorial in function, and there are other differences quite sufficient to form a pretty wide gap between the Anthuridee and Phreatoicus.

With the Idoteidee, Phreatoicus agrees fairly well in the general shape of the body, in the antennæ and to a less extent in the mouth parts, except that the mandible has a well developed palp in Phreatoicus, but none in the species of the Idoteider. It is probable however that this should not be considerod a very important point, as in the Amphipoda we have the mandibular palp present in widely separated genera while it is sometimes absent in others which are otherwise closely similar to genera in which the palp is present. Thus the old genus Montagua, Spence Bate, is considered by Stebbing to be divisible into Stenothoe, the species of which have no mandibular palp, and Metopa in which the palp is present.*

* Report on the "Challenger" Amphipoda, p. 293. 
A much more important difference between Phreatoicus and the Idoteidce is however to be found in the abdomen and particularly in the last pair of appendages - the uropoda. In Phreatoicus these are fairly normal in character and not very dissimilar from those found in Asellus and other genera, while in the Idoteidoe they are specially modified into flat subrectangular plates to cover the lower surface of the abdomen and to protect the pleopoda. In some species of the Idoteida, however, there is a rudimentary second ramus, showing that this plate is formed from the typical uropod consisting of a basal joint and two rami, the inner ramus being rudimentary or absent, and the formation of the protecting plate is probably a special modification of comparatively recent date. On the whole the aftinities of Phreatoicus to the Idoteide may be considered to be somewhat greater than its affinities to the Anthuridce. In the same way we might compare Phreatoicus with the Arcturida, a group that must be placed near the Idoteida.

When we come to compare Phreatoicus with the Asellidoe we see at once that the form of the body is very different from that usually found in the Asellide, but on examining in detail we find that there is a fairly close resemblance in many other respects. The head, antennæ and mouth parts are all in close agreement, except that the head is flattened in the Asellidce; the resemblance in the mouth parts is on the whole very close and is somewhat striking, considering the great difference in the general appearance of the animal. I have been able to take Sars' description of the mouth parts in Asellus aquaticus as my guide in describing those of Phreatoicus, and to follow that guide very closely. All the legs and the uropoda are also closely similar, the resemblance in some of the legs being quite as close as that in the mouth parts. It is in the abdomen and the pleopoda that we find the greatest difference between the two. In the Asellida the abdomen is usually depressed and formed of a single piece, though traces of other segments are sometimes present, the pleopoda lie closely under the abdomen and are usually protected by a more or less perfect operculum formed of the first pair of pleopoda. In Phreatoicus the abdomen is not depressed but somewhat compressed laterally, the six segments are all separate and well developed, the pleopoda hang vertically downwards from the segments of the abdomen and there is no operculum, the pleopoda being exposed below though protected laterally by the pleura of the abdominal segments.

These differences in the abdomen are pretty considerable, but from the traces of separate segments found in some of the species of the Asellide it is quite clear that the ancestors of the Asellides possessed an abdomen of six separate segments, and that these have gradually coalesced to form a single plate just as we see the same process going on at the present time in the Idoteida, where 
some species have the abdomen composed of four or five separate segments, other species with only two or three segments, and others again, like Idotea elongata, with the abdomen formed of a single piece.* The development of an operculum from the first pair of pleopoda would natuially follow from the flattening of the abdomen which would leave the pleopoda much exposed below. Thus Phreatoicus appears to have preserved the fully developed abdomen which must have been possessed by the ancestors of the Asellida, while in the latter this has been specially modified in accordance with the general flattening of the body, which would render a long jointed abdomen unsuitable and a source of danger to the animal, especially by the exposure to which it would subject the pleopoda.

There is one genus-Limnoria-sometimes classed under the Asellida, which differs from them and resembles Phreatoicus in possessing an abdomen of six separate segments, the pleopoda also are unprotected. Limnoria however resembles the other Asellida in the flat depressed body, and the segments of the abdomen though separate are short, so that Limnoria may very well be looked upon as an intermediate link between Phreatoicus and the Asellide. The great difference between the two latter is caused by the fact that the body in the Asellidee is flat and depressed, while it is somewhat compressed in Phreatoicus, and that consequently the Asellida are always represented as seen from above, while Phreatoicus is usually seen from the side. This difference in the form of the body though it gives quite a different appearance to the animal is probably not of very much importance from a systematic point of view, thus some of the species of Idotea differ very much in the shape of the body, and I think we must place Phreatoicus near to the Asellida, but forming a new family, the Phreatoicida, which bears to the Asellide much the same relation that the Caprellide do to the Cyamida among the Amphipoda. Limnoria will perhaps best be placed as a special subdivision of the Asellida, connecting them to some extent with the Phreatoicida.

I have not compared Phreatoicus with some other families of the Isopoda that it might well be compared with, such as, for intance, the Egide and the Sphaeromida, but from what has been already said it will readily be seen that it possesses various characters in common with these as well as with those already considered inasmuch as it preserves to a large extent the typical characters of the Isopoda, and thus occupies a more or less central position, around which the other families may be grouped.

The relation of Phreatoicus to its nearest allies may be graphically represented by the following hypothetical genealogical tree:

* See "Revision of the New Zealand Idoteidæ," Transactions N. Z. Inst., XXII., p. 199. 


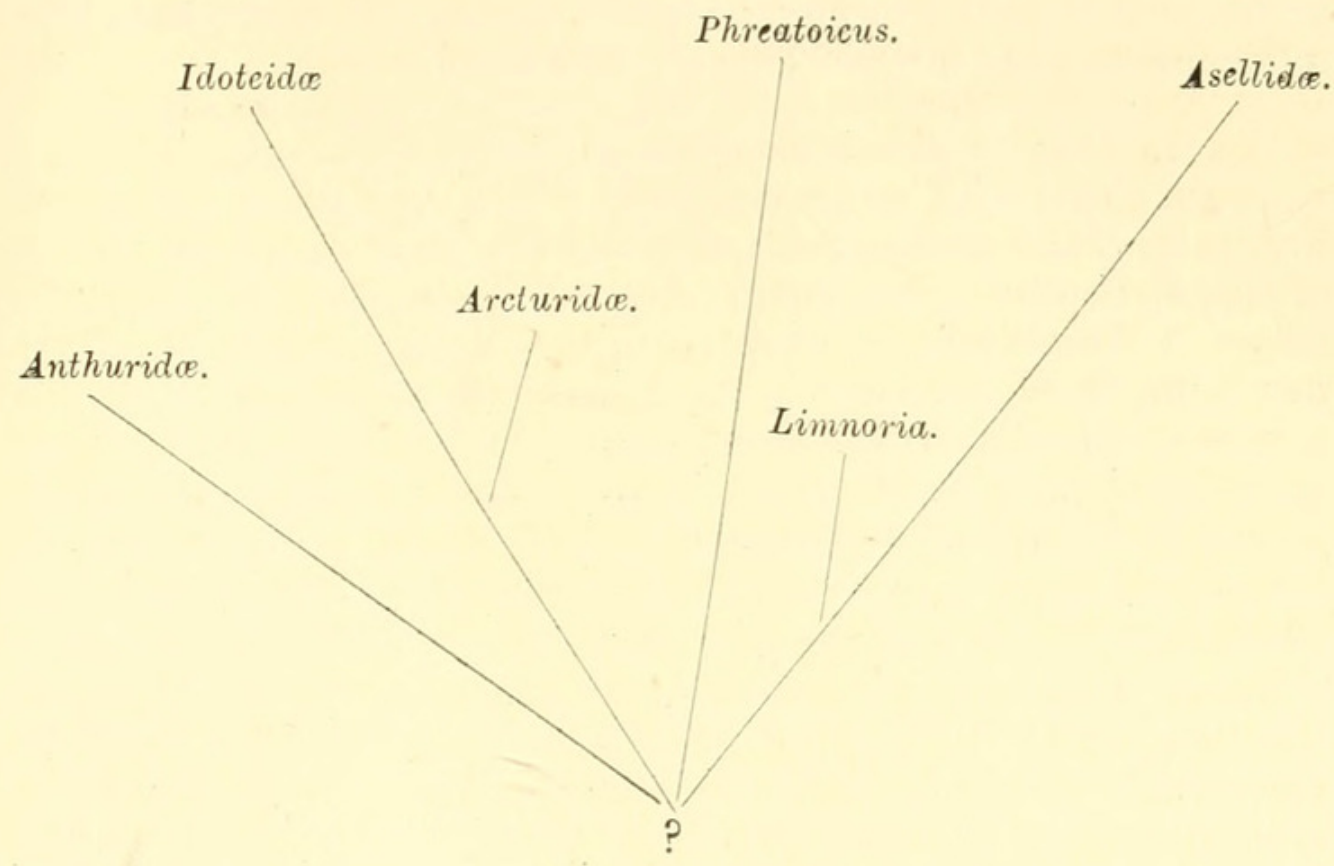

NOTES oN "ROCK-SHELTERS," oR "GIBBA-GUNYAHS," AT DEEWHY LAGOON.

By R. Etheridge, Junr.

SEvfral fine "Rock-shelters" may be seen along the escarpment of Hawkesbury Sandstone forming the southern boundary of the hollow wherein lies the Deewhy Lagoon, between Manly and Narrabeen. Some of these were examined by Messrs. G. H. Barrow, R. Jenkins, and the Writer, and the following notes obtained :-

The Shelters are of the usual type seen throughout the Port Jackson District, recesses in the escarpment, overhung by thick, more or less tabular masses of rock, in some cases dry and habitable, in others wet and apparently never used by the Aborigines. The first examined lay at the south-east end of the escarpment, where the latter almost abuts on the swampy ground of the lagoon. The length was twenty-nine feet, depth sixteen feet, height from floor to ceiling four feet, the total height inclusive of the rock covering nine feet six inches. Interments did not appear to have been made in this Shelter, or if they had, we failed to discover any remains. From the regular and undisturbed condition of the hearth-earth, I think it more than 


\section{$2 \mathrm{BHL}$ Biodiversity Heritage Library}

Chilton, Chas. 1891. "On a new and peculiar freshwater isopod from Mount Kosciusko." Records of the Australian Museum 1, 149-171.

https://doi.org/10.3853/j.0067-1975.1.1891.1249.

View This Item Online: $\underline{\text { https://www.biodiversitylibrary.org/item/31217 }}$

DOI: https://doi.org/10.3853/j.0067-1975.1.1891.1249

Permalink: https://www.biodiversitylibrary.org/partpdf/11411

\section{Holding Institution}

Harvard University, Museum of Comparative Zoology, Ernst Mayr Library

\section{Sponsored by}

Harvard University, Museum of Comparative Zoology, Ernst Mayr Library

\section{Copyright \& Reuse}

Copyright Status: NOT_IN_COPYRIGHT

This document was created from content at the Biodiversity Heritage Library, the world's largest open access digital library for biodiversity literature and archives. Visit BHL at https://www.biodiversitylibrary.org. 